\title{
PENGARUH GAYA KOGNITIF TERHADAP KEMAMPUAN KOMUNIKASI MATEMATIS MELALUI ANALISIS KOEFISIEN DETERMINASI DAN UJI REGRESI
}

\author{
Edy Saputra ${ }^{1}$, Rahmy Zulmaulida ${ }^{2}$ \\ ${ }^{1}$ Institut Agama Islam Negeri Takengon, Jalan Yos Sudarso,Takengon 24552, Indonesia \\ ${ }^{1}$ Institut Agama Islam Negeri Lhokseumawe, Jl. Banda Aceh-Medan, Lhokseumawe 24352, Indonesia \\ Email: edysaputra.esa@gmail.com \\ Email: rahmyzulmaulida@gmail.com
}

\begin{abstract}
Abstrak
Penelitian ini bertujuan untuk mengetahui pengaruh gaya kognitif pada pembelajaran Anchored Instruction terhadap kemampuan komunikasi matematis siswa melalui analisis koefisien determinasi dan uji regresi. Jenis penelitian yang digunakan adalah penelitian korelasional yang bertujuan menyelidiki sejauh mana variasi pada satu variabel berkaitan dengan variasi pada satu atau lebih variabel lain, berdasarkan koefisien korelasi dan persamaan regresi. Teknik pengumpulan data dalam penelian ini menggunakan tes GEFT dan tes kemampuan komunikasi matematis. Tes diberikan pada 25 orang siswa SMA kelas X. Populasi pada penelitian ini adalah seluruh siswa SMA kelas $\mathrm{X}$ dengan sampel yang dipilih secara purposive sampling. Analis data dalam penelitian ini menggunakan kooefisien determinasi dan regresi sederhana untuk menentukan besar pengaruh dan prediksi perubahan antar variabel. Berdasarkan hasil penelitian diperoleh kesimpulan bahwa terdapat pengaruh gaya kognitif tipe Field Dependent dan Field Independen pada pembelajaran Anchored Instruction terhadap kemampuan komunikasi matematis siswa melalui analisis koefisien determinasi dan uji regresi.
\end{abstract}

Kata kunci: Gaya Kognitif, Komunikasi Matematis

\begin{abstract}
This study aims to determine the influence of cognitive styles on Anchored Instruction learning toward students' mathematical communicative skills through coefficient analysis of determination and regression test. The type of research used was correlational research aimed at investigating the extent to which variations in one variable were related to the variations in one or more other variables, this based on correlation coefficients and regression equations. The data collection techniques in this study were GEFT tests and mathematical communicative capability tests. The test was given to 25 high school students in grade $X$. The population in this study was all high school students in grade $X$ with purposive sampling of the selected samples. Data analysis in this study used simple cooefisient determination and regression to determine the amount of influence and to predict changes among variables. Based on the results of the study, it was concluded that there was an influence of cognitive styles of Field Dependent and Independent Field types on Anchored Instruction learning toward students' mathematical communicative skills through coefficient analysis of determination and regression test.
\end{abstract}

Keyword: Cognitive Styles, mathematical communication skills

\section{PENDAHULUAN}

Pembelajaran yang selama ini dilakukan di sekolah masih menemui berbagai hambatan diantaranya kesulitan dalam mengintegrasikan pemakaian teknologi pada pembelajaran, kesulitan dan pemenuhan fasilitas teknologi informasi dan penyediaan bahan ajar yang mengikuti tren modernisasi (Sabaruddin et al., 2020). Berbagai kesulitan ini menjadi masalah tersendiri dan menjadi titik lemah yang harus dihadapi selama proses pembelajaran dilaksanakan. Hal ini akan menjadi kemunduran 
pada pembelajaran di era revolusi industri4.0. Dampak yang timbul dari berbagai kesulitan yang terjadi akan berpengaruh pada kualitas pembelajaran dan keterbatasan siswa dalam mengakses informasi dalam mendukung penguatan materi yang dipelajarinya.Jika hal ini terus berlanjut pendidikan di Indonesia tidak dapat berkembang pesatdan akan terus tertinggal dari negara-negara lain.

Dalam proses pembelajaran melibatkan berbagai aktivitas berpikir yang sangat kompleks. Pembelajaran tidak hanya melakukan aktivits menghafal sesuatu tetapi juga melibatkan bagaimana menemukan dan memberikan pemahaman penuh sampai pada tingkat pembelajaran menjadi bermakna (Zulmaulida et al., 2018). Belajar melibatkan prinsip-prinsip dasar psikologi, yaitu belajar aktif, belajar lewat interaksi sosial dan lewat pengalaman sendiri (Sutarto, 2017). Untuk itu proses pembelajaran yang dilakukan harus dapat membangun interaksi antar semua unsur yang terlibat, seperti interaksi siswa dengan siswa, siswa dengan media, dan siswa dengan lingkungan belajaranya (E. Saputra et al., 2018). Interaksi yang terjadi akan membangun pengalaman belajar aktif dan mencirikan sikap/psikologi pada setiap siswa yang terlibat dalam pembelajaran. Menjawab kondisi belajar yang demikian diperlukan model pembelajaran yang dapat mengakomodasi pembelajaran yang bisa membuat siswa aktif di dalamnya. Model pembelajaran yang menjadi pilihan pada penelitian ini adalah Anchored Instruction. Pelaksanaan pembelajaran ini menjadikan siswa aktif dalam belajar sehingga tujuan pembelajaran yang diharapakan akan tercapai sesuai dengan yang diharapkan.

Anchored Instruction (AI) adalah pembelajaran yang dirancang dengan melibatkan berbagai makna dari masalah yang dapat dikembangkan menjadi suatu kasus atau tema yang dapat dipecahkangurudalam mengeksplorasisehingga menjadi sebuah penemuan (Edy Saputra, 2012). Anchored Instruction adalah sebuah pembelajaran yang menggabungkan antara kurikulum dan pengajaran sehingga dapat memberikan kesempatan bagi siswa untuk belajar dari pengalaman untuk memahami dan memecahkan masalah otentik yang timbul dalam berbagai percobaan dan koneksi keilmuan. Anchored Instruction mengharuskan siswa belajar dalam pengorganisasian kelompok, sehingga interaksi antar siswa dapat terus diamati selama pembelajaran berlangsung. Aktivitas belajar demikian ini memungkinkan pengukuran prestasi belajar dapat dilakukan selama pembelajaran tidak hanya setelah pembelajaran. Diskusi kelompok yang dilakukan akan menghasilkan solusi yang mungkin berbeda oleh masing-masing kelompok namun dapat dipertanggungjawabkan.

Faktor lain yang dapat menyebabkan perbedaan pada hasil belajar matematika adalah salah satunya kemampuan awal siswa dan aktivitas kognitifnya (Wulan, 2019). Setiap siswa mempunyai perbedaan pada kemampual awal nya sebelum pembelajaran sehingga pembelajaran yang dilalui oleh setiap siswa akan memiliki hambatan yang berbeda pula. Aktivitas koqnitif dalam hal ini gaya kognitif siswa pada tipe Field Dependent (FD) dan Field Independent (FI) juga menjadi satu faktor lainnya yang menjadi penentu aktivitas belajar siswa dalam pembelajaran AI. Siswa yang mempunyai kemampuan awal tinggicenderung lebih cepat memahami dan menemukan solusi dari masalah yang diajukan, namun bisa terjadi sebaliknya pada siswa yang mempunyai kemampuan sedang, mereka akan lebih lama memahami dibandingkan dengan siswa yang mempunyai kemampuan tinggi, begitu juga dengan siswa yang mempunyai kemampuan rendah. Selain itu gaya koqnitif yang berbeda pada setiap diri siswa akan menjadi faktor penentu lainnya untuk dapat memahami dan menemukan solusi darai masalah yang disampaikan. Maka dari itu diperlukan peran guru yang dominan dalam melaksanakan kegiatan belajar sebagai pembaharuan dari model belajara yang sering digunakan. AI menjadi solusi dimana siswa dapat bertukar informasi.

Berdasarkan observasi dan wawancara yang dilakukan di sekolah diperoleh informasi dari guru matematika sebagian siswa kurang memahami materi, konsep, prinsip, serta rumus pada materi yang diajarkan, dikarenakan kurangnya kemampuan guru dalam mengaitkan konsep, prinsip, serta keterampilan dengan pengalaman sehari-hari siswa. Dan kebanyakan dari sebagian siswa, mereka hanya menghafal rumusnya saja tanpa memahami konsep dari rumus yang sudah dijelaskan. 
Hambatan dalam aktivitas belajar ini dapat menghambat kemampuan matematis yang dimiliki siswa. Salah satu kemampuan yang dimaksud adalah komunikasi matematis.Kemampuan komunikasi matematis digunakan untuk menyelesaikan dan memahami permasalahan dengan benar sesuai dengan permintaan soal yang diberikan. Dengan meningkatkan kemampuan komunikasi matematis diharapkan siswa mampu menciptakan ketertarikan untuk mengetahui hal-hal yang dapat merangsang pemikiran, ide-ide, prinsip dan konsep-konsep materi yang dapat mengembangkan keterampilannya dalam berpikir maupun merancang sesuatu, sehingga ia akan miningkatkan produktifitas di masa yang akan dating (Hikmah et al., 2019).

Dari pemaparan yang terurai tersebut, penulis akan mengkaji analisis koefisien determinasi dan uji regresi pada pengaruh gaya kognitif terhadap kemampuan komunikasi matematis. Tujuan penulis mengangkat judul ini yaitu untuk menganalisis pengaruh gaya kognitif pada pembelajaran Anchored Instruction terhadap kemampuan komunikasi matematis siswa melalui analisis koefisien determinasi dan uji regresi.

\section{METODE PENELITIAN}

Keberkaitan antara satu variable dengan variabel lain dan variasi dari tiap variabel berdasarkan koefisien korelasi pada penelitian ini akan dianalisis dengan penelitian korelasional (corelational research)((Andi Ibrahim, Asrul Haq Alang, Madi, 2018). Populasi dalam penelitian ini adalah seluruh siswa SMAN kelas X di Aceh Tengah dipilih sebagai populasi dalam penelitian ini dengan 25 orang siswa kelas $\mathrm{X}$ digunakan sebagai sampel yang dipilih secara purposive sampling. Untuk memperjelas alur penelitian yang dilakukan diperlihatkan desain penelitian seperti pada Gambar 1 berikut:

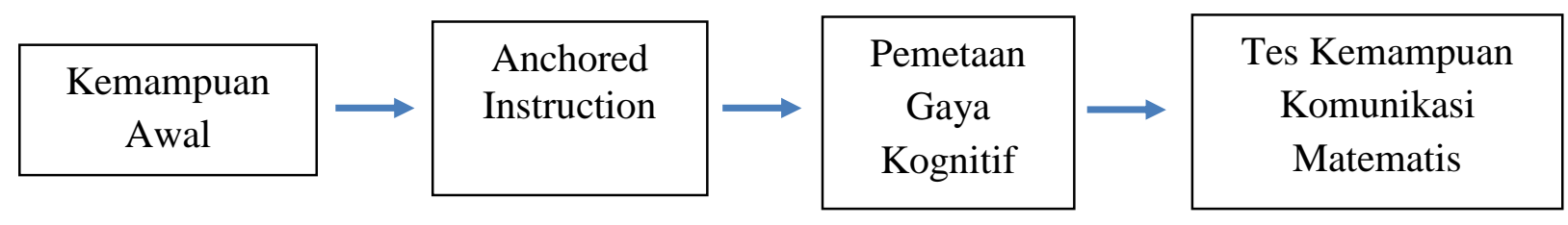

Gambar 1. Flowchart Alur Penelitian

Teknik pengumpulan data dalam penelian ini menggunakan tes GEFT dan tes kemampuan komunikasi matematis. Tes diberikan pada 25 orang siswa SMA kelas X di Takengon Aceh Tengah. Populasi pada penelitian ini adalah seluruh siswa SMA kelas X di Takengon Aceh Tengah dengan sampel yang dipilih secara purposive sampling. Analis data diperlukan untuk memperoleh kesimpulan yang dianalisis dengan menghitung kooefisien determinasi dan regresi sederhana untuk menentukan besar pengaruh dan prediksi perubahan antar variabel.

\section{HASIL PENELITIAN DAN PEMBAHASAN}

Hasil penelitian yang dilakukan pada 25 orang siswa sebagai sampel penelitian diperoleh hasil sebagai berikut:

\section{a. Temuan Kemampuan Awal Matematis}

Nilai kemampuan awal siswa diperoleh dari hasil ulangan materi sebelumnya. Nilai kemampuan awal diperlukan dalam penelitian ini untuk menunjukkan bahwa kemampuan siswa sebelum pembelajaran adalah heterogen. Selanjutnya kemampuan awal siswa akan dikategorikan dalam tiga tingkatan yaitu tinggi, sedang, dan rendah. Hasil pengkategorian KAM siswa dapat dilihat pada table berikut. 
Tabel 1. Kategori KAM Siswa

\begin{tabular}{|c|c|c|}
\hline \multicolumn{3}{|c|}{ KAM } \\
\hline Tinggi & Sedang & Rendah \\
\hline 90 & 80 & 70 \\
\hline 90 & 80 & 70 \\
\hline 90 & 80 & 70 \\
\hline 90 & 80 & 70 \\
\hline 90 & 80 & 65 \\
\hline 85 & 80 & 65 \\
\hline 85 & 80 & 65 \\
\hline 85 & 80 & \multirow{2}{*}{} \\
\hline & 75 & \\
\cline { 1 - 2 } & 75 & \\
\hline
\end{tabular}

Cara pengkategorian tingkat KAM siswa menggunakan kaidah dalam sebaran data normal dengan rumus $\frac{S M-S M}{B}=\frac{9-6}{3}=8,33$. Dari hasil pengujian diperoleh nilai siswa pada kategori rendah ada pada interval $65-73,33 \approx 73$, interval kategori sedang ada pada $74-82,33 \approx 82$, dan interval tinggi pada $82-90,33 \approx 90$.

\section{b. Data deskriptif Gaya Kognitif}

Hasil instrument tes Group Embedded Figures Test (GEFT) yang dilakukan untuk memetakan gaya koqnitif siswa tipe Field Dependent (FD) dan Field Independent (FI) pada pembelajaran Anchored Instructionyang di adaptasi dari (Alamolhodaei, 2002) diperoleh hasil seperti pada tabel berikut.

Tabel 2. Interpretasi Skor GEFT

\begin{tabular}{|c|c|}
\hline Gaya Kognitif & Perhitungan \\
\hline Field Dependent & $S<\bar{x}-\frac{1}{4} S$ \\
\hline Field Independent & $S<\bar{x}+\frac{1}{4} S$ \\
\hline Field Neutral & $\bar{x}-\frac{1}{4} S<S<\bar{x}+\frac{1}{4} S$ \\
\hline
\end{tabular}

Hasil pengelompokan siswa dalam kategori Field Dependent dan Field Independen adalah sebagai berikut.

Tabel 3. Skor Gaya Kognitif

\begin{tabular}{|c|c|c|}
\hline FD & FI & Netral \\
\hline 14 & 18 & 17 \\
\hline 15 & 18 & 17 \\
\hline 16 & 18 & 17 \\
\hline 16 & 19 & 17 \\
\hline 15 & 19 & 17 \\
\hline
\end{tabular}




\begin{tabular}{|l|l|l|}
\hline 16 & 19 & 17 \\
\hline 16 & 18 & 17 \\
\hline 16 & 19 & 17 \\
\hline & & 17 \\
\hline
\end{tabular}

Table 3 di atas menunjukkan banyaknya siswa yang memiliki gaya kognitif FD ada 8 orang siswa, FI ada 8 orang siswa dan netral 9 orang siswa. Sebaran jumlah siswa menunjukkan kelompok siswa yang ada memiliki tipe gaya koqnitif yang berbeda dengan jumlah yang sama pada masing-masing tipe FD dan FI.

\section{c. Data Deskriptif Kemampuan Komunikasi Matematis}

Kemampuan komunikasi matematis siswa setelah pembelajaran diperoleh setelah semua proses pelaksaan pembelajaran selesai dilakukan. Hasil tes adalah skor dari instrumen tes kemampuan komunikasi matematis yang di susun. Hasil yang diperoleh dapat dilihat pada Tabel 5 berikut.

Tabel 5. Hasil Tes Kemampuan Komunikasi Matematis

\begin{tabular}{|c|c|c|c|c|c|}
\hline \multirow{2}{*}{$\begin{array}{c}\text { Skor } \\
\text { Ideal }\end{array}$} & \multirow{N}{*}{$\mathbf{N}$} & \multicolumn{4}{|c|}{ Post-test } \\
\cline { 3 - 6 } & & $\mathbf{X}_{\min }$ & $\mathbf{X}_{\max }$ & $(\bar{x})$ & SD \\
\hline 20 & 25 & 13 & 19 & 15,42 & 1,72 \\
\hline
\end{tabular}

Hasil pada Tabel 5 di atas menunjukkan bahwa hasil tes kemampuan komunikasi matematis 25 orang siswa memperoleh skor terkecil 13 dan terbesar 19 dari skor ideal 10. Rata-rata skor adalah 15,42 dan simpangan bakunya 1,72. Hasil ini menunjukkan tidak terdapat selisih yang besar skor antar setiap siswa yang mengikuti tes.

\section{d. Koefisien Determinasi}

Untuk melihat pengaruh yang ditimbulkan dari gaya koqnitif terhadap kemampuan komunikasi matematis siswa setelah pembelajaran diperlukan koefisien determinasi. Koefisien determinasi ini diperoleh dari hasil pengujian pengaruh tipe gaya koqnitif FD terhadap kemampuan komunikasi matematisnya mengunakan IBM SPSS 21 dengan output sebagai berikut.

\section{Tabel 6. Koefisien Determinasi FD}

\begin{tabular}{|l|r|r|r|r|}
\hline Model & $\mathrm{R}$ & $\mathrm{R}$ Square & $\begin{array}{c}\text { Adjusted R } \\
\text { Square }\end{array}$ & $\begin{array}{c}\text { Std. Error of } \\
\text { the Estimate }\end{array}$ \\
\hline \hline 1 & $.115^{\mathrm{a}}$ & .013 & -.151 & 1.14708 \\
\hline
\end{tabular}

Dari tabel 6 di atas terdapat nilai R Square yang dapat diartikan sebagai determinan korelasi sebesar 0,013 yang menjelaskan bahwa $1,3 \%$ perubahan kemampuan komunikasi matematis siswa dipengaruhi oleh gaya kognitif tipe FD dan $98,7 \%$ adalah pengaruh yang disebabkan oleh berbagai variabel lainnya. Nilai 0,115 merupakan nilai korelasi yang diperoleh dari hasil pengujian yang dapat diartikan bahwa gaya kognitif tipe FD mempengaruhi kemampuan komunikasi matematis siswa.

Selanjutnya dilakukan pengujian koefisien determinasi pengaruh tipe gaya koqnitif FI terhadap kemampuan komunikasi matematisnya dengan IBM SPSS 21 dengan output sebagai berikut. 


\section{Tabel 7. Koefisien Determinasi FI}

\begin{tabular}{|l|r|r|r|r|}
\hline Model & \multicolumn{1}{|c|}{$\mathrm{R}$} & $\mathrm{R}$ Square & $\begin{array}{c}\text { Adjusted R } \\
\text { Square }\end{array}$ & $\begin{array}{c}\text { Std. Error of } \\
\text { the Estimate }\end{array}$ \\
\hline 1 & $.428^{\mathrm{a}}$ & .183 & .047 & 1.72603 \\
\hline
\end{tabular}

Dari tabel 7 di atas terdapat nilai R Square sebesar 0,183 yang menjelaskan bahwa 18,3\% perubahan kemampuan komunikasi matematis siswa dipengaruhi oleh gaya kognitif tipe FI dan $81,7 \%$ sisanya dipengaruhi oleh variabel lainnya. Nilai korelasi yang diperoleh adalah 0,428 yang dapat diartikan bahwa gaya kognitif tipe FI mempengaruhi kemampuan komunikasi matematis siswa.

Hasil pengujian yang dilakukan diperoleh fakta bahwa gaya kognitif yang dimiliki siswa dengan tipe FI memberikan kontribusi yang lebih tinggi daripada FD terhadap kecakapannya pada penguasaan kemampuan komunikasi matematis. Hasil yang diperoleh yaitu FI memberi pengaruh 18,3\% lebih tinggi dari FD yang hanya memberi pengaruh 1,3\% saja. Hasil ini sejalan dengan penelitian yang dilakukan ( Nurmalia et al., 2019) yang menyatakan bahwa siswa dengan gaya kognitif tipe FI memiliki keterampilan komunikasi matematis lebih dari FD. Perbedaan antara FI dan FD dapat terlihat pada siswa dengan gaya kognitif FI memiliki kemampuan untuk menganalisis yang lebih baik dari FD, lebih suka bekerja secara individu, dan tidak berorientasi sosial.

\section{e. Regresi sederhana}

Untuk mendapatkan pengaruh gaya kognitif pada pembelajaran Anchored Instruction terhadap kemampuan komunikasi matematis siswa dilakukan uji analisis regresi sederhana dengan bantuan IBM SPSS 21. Output hasil perhitungan regresi sederhana pada gaya koqnitif tipe FD sebagai berikut.

Tabel 8. Regresi

\begin{tabular}{|rl|r|r|r|r|r|}
\hline \multirow{2}{*}{ Model } & \multicolumn{2}{|c|}{$\begin{array}{c}\text { Unstandardized } \\
\text { Coefficients }\end{array}$} & $\begin{array}{l}\text { Standardized } \\
\text { Coefficients }\end{array}$ & \multirow{2}{*}{ Sig. } & \\
\cline { 2 - 7 } & \multicolumn{1}{|c|}{ B } & Std. Error & \multicolumn{1}{c|}{ Beta } & & \\
\hline \multirow{2}{*}{1} & (Constant) & 17.526 & 7.176 & & 2.442 & .050 \\
& FD & .105 & .372 & .115 & .283 & .787 \\
\hline
\end{tabular}

Persamaan regresi $\hat{Y}=17,526+0,105 \mathrm{X}$ adalah persamaan yang dihasilkan dari output pengujian pada Tabel $8 \mathrm{di}$ atas. Bentuk dari persamaan ini dapat digunakan untuk menjelaskan dan mengambil kesimpulan mengenai pengaruh gaya kognitif tipe FD (X) dan kemampuan komunikasi matematis (Y). Hasil yang diperoleh dari persamaan regresi ini dapat diartikan bahwa arti setiap kenaikan satu satuan skor FD akan meningkatkan 0,105 satuan kemampuan komunikasi matematis dengan konstanta 17,526.

Selanjutnya output hasil perhitungan regresi sederhana pada gaya koqnitif tipe FI sebagai berikut.

Tabel 9. Regresi

\begin{tabular}{|l|c|c|c|c|c|}
\hline Model & \multicolumn{2}{|c|}{$\begin{array}{c}\text { Unstandardized } \\
\text { Coefficients }\end{array}$} & $\begin{array}{c}\text { Standardized } \\
\text { Coefficients }\end{array}$ & t Sig. \\
\cline { 1 - 5 } & B & Std. Error & Beta & \\
\hline
\end{tabular}




\begin{tabular}{|ll|r|r|r|r|r|}
\hline \multirow{2}{*}{1} & (Constant) & -4.375 & 17.271 & & -.253 & .808 \\
& FI & 1.000 & .863 & .428 & 1.159 & .291 \\
\hline
\end{tabular}

Persamaan regresi yang diperoleh dari output pengujian Tabel 9 di atas adalah $\hat{Y}=-4,375+1,000 \mathrm{X}$. Untuk menjelaskan dan mengambil kesimpulan mengenai pengaruh gaya kognitif tipe FI (X) dan kemampuan komunikasi matematis $(\mathrm{Y})$ dapat diperoleh dari persamaan regresi ini. Persamaan ini memiliki arti setiap kenaikan satu satuan skor FI akan meningkatkan 1,000 satuan kemampuan komunikasi matematis dengan konstanta $-4,375$.

Bentuk persamaan regresi yang diperoleh dari hasil pengujian yang dilakukan denagn bantuan IMB SPSS 21 menunjukkan bahwa peran gaya kognitif tipe FI memberi dampak peda kenaikan kemampuan komunikasi matematis siswa yang lebih tinggi dari gaya kognitif tipe FD. Senada dengan penelitian yang dilakukan (Prastiti, 2010) menemukan siswa yang memiliki gaya kognitif FI pencapaian kemampuan komunikasi matematisnya lebih unggul dibandingkan dengan siswa yang memiliki gaya kognitif FD. Kenaikan tersebut terlihat pada pertambahan setiap kenaikan skor pada persamaan regresi $\hat{Y}=-4,375+1,000 \mathrm{X}$ akan memberi perubahan skor kemampuan komunikasi matematis lebih tinggi dari persamaan $\hat{Y}=17,526+0,105 X$. Hubungan antara gaya koqnitif dan kemampuan komunikasi matematis ini memberi kesimpulan bahwa perbedaan pada gaya kognitif yang dimiliki siswa akan ikut merubah kemampuan komunikasi matematisnya dan bergantung dengan proses pembelajaran yang dilakukan.

\section{KESIMPULAN}

Kesimpulan yang dapat diperoleh dari perhitungan dan analisis data yang dilakukan bahwa terdapat pengaruh gaya kognitif tipe Field Dependent dan Field Independen pada pembelajaran Anchored Instruction terhadap kemampuan komunikasi matematis siswa melalui analisis koefisien determinasi dan uji regresi.

\section{REFERENCES}

Andi Ibrahim, Asrul Haq Alang, Madi, B. \& D. (2018). Metodologi Penelitian. Gunadarma Ilmu.

Alamolhodaei, H. (2002). Students' cognitive style and mathematical word problem solving. Journal of the Korea Society of Mathematical Education, 6(2), 171-182.

Han, E. S., \& goleman, daniel; boyatzis, Richard; Mckee, A. (2019). 済無No Title No Title. Journal of Chemical Information and Modeling, 53(9), 1689-1699.

Hikmah, A., Roza, Y., \& Maimunah, M. (2019). Analisis Kemampuan Komunikasi Matematis Siswa $\begin{array}{lllll}\text { Smp Pada Soal Spldv. Media Pendidikan Matematika, } & 7(1), 29 .\end{array}$ https://doi.org/10.33394/mpm.v7i1.1428

Prastiti, T., D. (2010). Implementasi Realistic Mathematics Education dengan Memperhatikan Gaya Kognitif Siswa dan Pengaruhnya terhadap Kemampuan Komunikasi dan Pemecahan Masalah Matematika SMP. In Jurnal Pendidikan dan Pembelajaran (JPP) (Vol. 16, Issue 1). http://journal.um.ac.id/index.php/pendidikan-dan-pembelajaran/article/view/2609

Sabaruddin, Marzuki, \& Khairunnisak. (2020). Pandemic Covid-19: The Opportunities and Challenges to Using ICT in Mathematics Learning. IJEBD International Journal of Entrepreneurship And Business Development EISSN 2597-4785 PISSN 2597-4750, 3(4), 409- 
414.

Saputra, E., Wahyudin, \& Dahlan, J. A. (2018). The enhancement of spatial levels reviewed from students' cognitive styles. Journal of Physics: Conference Series, 1028(1). https://doi.org/10.1088/1742-6596/1028/1/012093

Saputra, Edy. (2012). Pengaruh Penggunaan model Pembelajaran Anchored Intruction Terhadap Peningkatan Kemampuan Komunikasi Matematis dan Self Concept Siswa. Universita Pendidikan Indonesia.

Sutarto, S. (2017). Teori Kognitif dan Implikasinya Dalam Pembelajaran. Islamic Counseling: Jurnal Bimbingan Konseling Islam, 1(2), 1. https://doi.org/10.29240/jbk.v1i2.331

Wulan, E. R. (2019). Gaya Kognitif Field-Dependent Dan Field-Independent Sebagai Jendela Profil Pemecahan Masalah Polya Dari Siswa Smp. Factor M, 1(2), 123-142. https://doi.org/10.30762/f_m.v1i2.1503

Zulmaulida, R., Wahyudin, \& Dahlan, J. A. (2018). Watson-Glaser's Critical Thinking Skills. Journal of Physics: Conference Series, 1028(1), 12094. https://doi.org/10.1088/17426596/1028/1/012094 